\title{
Lutropin-Choriogonadotropic Hormone Receptor
}

National Cancer Institute

\section{Source}

National Cancer Institute. Lutropin-Choriogonadotropic Hormone Receptor. NCI

Thesaurus. Code C158719.

Lutropin-choriogonadotropic hormone receptor (699 aa, $79 \mathrm{kDa}$ ) is encoded by the human LHCGR gene. This protein plays a role in G protein-coupled receptor signaling mediated by luteinizing hormone and choriogonadotropin binding. 